\section{Florida Commercial Horticultural Production: Constraints Limiting Water and Nutrient Use Efficiency}

\author{
Craig D. Stanley ${ }^{1}$ and Gurpal Toor
}

ADDITIONAL INDEX WORDS. seepage subirrigation, drip irrigation, overhead, microsprinkler

\begin{abstract}
SuMMARY. Application of water and nutrients for horticultural production in Florida can be accomplished through many different methods. Often, the irrigation system that is used determines the potential use efficiency for both water and nutrients. Producers face many constraints, real and perceived, that affect management decisions. This article provides an overview of many of the constraints that are encountered and identifies those management practices that are most effective for overcoming these constraints with respect to commonly used irrigation systems. These constraints include those related to irrigation system design and capabilities, soil factors, cultural practices, management intensity, and economic and regulatory conditions. Ultimately, the goal of this discussion is to determine where future research efforts should be focused and what critical issues may be on the horizon that may affect the Florida horticultural industry.
\end{abstract}

A ny factor within a production system that inhibits, impairs, restricts, or reduces the availability of applied water or nutrients can certainly contribute to inefficient use of either of these inputs. It is essential to understand what these constraints are and how they may be overcome to more effectively manage inputs used in horticultural crop production as well as to minimize detrimental environmental consequences for Florida's natural soil and water resources. Economic constraints exist that inhibit adoption of certain practices that may not be cost-effective for production of specific crops. Environmental concerns with inefficient use of water and nutrients may overshadow economic constraints through imposed regulations and producers will have to comply with regulatory constraints while still seeking to make a profit. Although in many cases, physical constraints can dominate, more often than not, the intensity of management and the use of best management practices (BMPs) are the keys to success in overcoming these restrictions.

This discussion focuses on those constraints that affect water and nutrient application efficiency with respect to irrigation method and drainage. Specifically, the constraints

University of Florida, IFAS, Gulf Coast Research and Education Center, 14625 County Road 672, Wimauma, FL 33598

${ }^{1}$ Corresponding author. E-mail: cdstan@ufl.edu. operation and application characteristics; 2) the soil environment; 3 ) cultural management (i.e., mulch, raised bed, method of fertilization, and so on);4) operator management intensity; and 5) economic and regulatory constraints. The ultimate goal of this discussion is to determine where future research efforts should be focused and what critical issues may be on the horizon that may affect the horticultural industry.

The type of irrigation system that is used sets the potential for subsequent water and nutrient use efficiency. Although all irrigation system methods differ in degree of efficiency of application (Smajstrla et al., 2002a), improper design or operation of any system can further reduce the potential for water and nutrient use efficiency (Smajstrla et al., 2002c). Irrigation methods for horticultural crop production in Florida consist of subirrigation (seepage) using water table management, drip irrigation, microsprinkler, and overhead irrigation using large-area application are: 1) irrigation systems and their

\section{Irrigation system operation and application characteristics}

sprinklers (Simonne et al., 2007). Each system has been evaluated for application efficiency (Smajstrla et al., 2002a) that takes into account the amount of applied water actually reaching the target crop root zone versus the total amount of water pumped. Irrigation application efficiency, along with infiltration and other soil water and nutrient-holding characteristics, the ability to precisely manage applications, and the crop rooting characteristics all contribute to the effectiveness and efficiency of water and nutrient applications (Smajstrla et al., 2002a).

Although an in-depth discussion of operation characteristics for each irrigation system (Smajstrla et al., 2006b) is not presented here, there are inherent characteristics of each that can affect water and nutrient use efficiency. A system factor such as application coverage (gross area versus net cropped area) can contribute greatly to the efficiency of application. Application losses as a result of evaporation or surface runoff and subsurface water movement have very important impacts on both nutrient and water use efficiency. Another aspect of an irrigation system that can be very important is its ability to apply fertilizer in an efficient manner. A third important aspect of irrigation management is the ability to schedule irrigation applications according to crop demands (Haman and Smajstrla, 2002; Smajstrla et al., 2006a). Irrigation system choice can affect the degree to which effective irrigation scheduling can be accomplished. Drip irrigation and microsprinkler systems have the most potential to efficiently meet crop needs by nature of their design (Smajstrla et al., 2002b).

\section{Soil environment constraints}

Soil physical and chemical properties are major factors that limit water and nutrient use efficiency (Haman and Izuno, 2003). Again, any soil factor that contributes to the inefficiency of water and nutrient use can be considered a constraint that needs to be overcome. These factors include

\begin{tabular}{llll}
\hline $\begin{array}{l}\text { Units } \\
\begin{array}{l}\text { To convert U.S. to SI, } \\
\text { multiply by }\end{array}\end{array}$ & U.S. unit & SI unit & $\begin{array}{l}\text { To convert SI to U.S., } \\
\text { multiply by }\end{array}$ \\
\hline 0.4047 & acre $(\mathrm{s})$ & ha & 2.4711 \\
0.3048 & $\mathrm{ft}$ & $\mathrm{m}$ & 3.2808
\end{tabular}


texture or the particle size distribution of a soil and the cation exchange capacity (CEC) that defines the ability of the soil to chemically bind cations in the soil profile. Because Florida soils are quite diverse in characteristics, especially when considering the differences between the very sandy mineral soils and the organic soils, the constraints associated with either are also diverse. Most soil-related constraints are associated with sandy soils and the discussion here concentrates on these. Soils with low water and nutrient-holding capacity provide little room for inefficiencies of irrigation or fertilizer application. Many soils used for horticultural production in Florida are very sandy in nature and are typically low in organic matter that contributes to a low CEC. When seasonal fertilizer amounts are applied at one time, these sandy soil characteristics result in a growing environment where these nutrients are very vulnerable to leaching losses from inefficient irrigation or heavy rainfall. Management of these soils to overcome these constraints is benefitted by application of no more water and nutrients than can be held in the rooting zone of the crop at any one time and may require multiple daily applications. Because heavy rainfall events in Florida are not uncommon, adequate drainage characteristics of production areas are critical. The ability to drain a field when needed is greatly affected by topography and presence of (or lack of) a high naturally occurring water table and can contribute to reducing or enhancing water and nutrient use efficiency depending on design and management.

\section{Cultural management factors}

There are many cultural factors that can contribute to overcoming constraints that are inherent with irrigation systems and the soil environments. For example, the use of bedded culture versus nonbedded culture can protect root zone waterlogging during heavy rainfall periods. Furthermore, the use of plastic mulch can protect applied fertilizer from leaching during the same periods as well as reduce evaporation and facilitate weed and other pest control.

Bedding and plastic mulch alone have become the norm for many highvalue horticultural crops. Although op- tions for fertilization procedures are greatly affected by irrigation system, this cultural management decision can be critical for reducing nutrient losses. The use of coated fertilizer materials that provides for controlled release of nutrients is an option when dry fertilizer application is necessary. Regardless of type of fertilizer used or the method of application, recommendations based on plant nutrient requirements (Simonne and Hochmuth, 2007) as to the quantity of fertilizer needed to grow a crop can be viewed as a constraint by producers. The decision as to how much fertilizer should be applied initially determines the potential nutrient losses that can happen as a result of the applied amounts not being used by the crop for production. In some instances, excessive fertilizer amounts can be viewed by producers as justified to provide "insurance" to protect the investment they have made in their crop. Even under these circumstances, management practices such as double-cropping or cover-cropping to use residual nutrients can minimize nutrient losses to groundwater and surface water resources.

\section{Intensity of management constraints}

Probably the most underconsidered yet most important constraint to water and nutrient use efficiency is that which concerns the producer and intensity of management required to overcome any physical constraints his or her production system encounters. One can have the most efficient irrigation system and still experience water and nutrient losses if it is not managed properly. Decisions with respect to scheduling water and nutrient applications, system maintenance, and repair can greatly affect efficient water and nutrient use. Many types of water and nutrient BMPs have been developed over the years to give producers options to achieve production goals while maintaining efficient water and nutrient use, but implementation of such practices, to a large degree, is still up to the manager him- or herself.

\section{Other constraints}

Other factors that producers may view as constraints that can affect water and nutrient use efficiency include economic investment costs and imposed regulatory constraints. Although this discussion does not dwell on these, they are often perceived by producers as real barriers to reaching production goals. Methods and systems that maximize water and nutrient use efficiency may exist, but the real and/or perceived economic cost may be seen as unjustified. Regulatory requirements are constantly becoming more stringent to protect natural resources and, although necessary, they can be viewed as an imposition by the producers if they inhibit or force change from normal operating procedures.

For the remainder of this discussion, we concentrate on addressing two specific questions regarding these constraints and how they relate to different irrigation systems for achieving water and nutrient use efficiency.

\section{Question 1: What are the constraints that limit water and nutrient use efficiency when using the following irrigation methods: seepage subirrigation, drip irrigation, microsprinkler, and overhead sprinkler?}

Seepage subirrigation. Seepage subirrigation uses field water table management to provide water for crop production (Smajstrla et al., $2006 \mathrm{~b}$ ). This system requires the following three components to be successful: 1) a readily available source of large quantities of water; 2 ) a soil that has a naturally high water table; and 3 ) a soil with physical characteristics that allow both rapid infiltration and drainage. This system is typically used on very sandy soils with a spodic layer having a naturally occurring high water table level (typically less than $1 \mathrm{~m}$ from the soil surface). Water is typically conveyed within the field by surface furrows or buried perforated pipe. For plastic-mulched field production of row crops, this system requires dry fertilizer to be applied in concentrated bands on top of raised beds (Geraldson, 1980). The fertilizer slowly comes into solution because upward capillary movement of water results from the elevated water table position below the bed. This system inherently can result in water applications two to three times beyond plant water use requirements simply because such large quantities are needed just to maintain the water 
table level itself as a result of surface and subsurface losses (Geraldson et al., 1965). Because this process affords little control other than the target water table level, traditionally as much as two to 2.5 times the University of Florida, Institute of Food and Agricultural Sciencesrecommended rate of fertilizer (Simonne and Hochmuth, 2007) has been applied as insurance against leaching losses that may occur as a result of heavy rainfall periods where the water table may be elevated to the surface. Because many crops grown with this system are very high-value crops and require large investments (greater than $\$ 20,000$ per ha) just to establish the crop, excessive fertilization and irrigation have been considered "cheap insurance" to protect the investments.

Much research and extension effort has been devoted to helping commercial producers overcome the obvious inefficiencies that can be associated with use the seepage subirrigation system. Probably the most difficult constraint is the legacy of this system in that it has been the traditional method used for much of the vegetable production for decades. It is a very effective irrigation system because the optimum environment provided for crop growth with respect to availability of water and nutrients is hard to match with other systems (Geraldson, 1962; Geraldson et al., 1965). In addition, it is a relatively low-cost system and requires minimal management intensity. However, because of its inefficiencies, the potential for overapplication of water and nutrient losses has become great concern for environmental regulatory agencies.

A modified design of the ditchconveyed seepage system (Stanley, 2004; Stanley and Clark, 1991), the fully enclosed subirrigation system (FES), using drip irrigation tubing buried below the tillage zone, has shown to be very effective in reducing water application amounts while still maintaining the target water table level. This savings results because much of the inefficiency of the seepage system attributed to surface runoff losses from the irrigation furrows is eliminated with the FES system because there is no surface water present. However, the use of banded dry fertilizer with FES remains the same as ditch-conveyed seepage subirrigation.

Drip IRrigation. The design and operation of a seepage subirrigation system is in stark contrast to the drip irrigation system that through its design (Haman and Smajstrla, 2003) has the ability to precisely apply water and nutrients directly into the root zone of the crop (Clark and Haman, 2003; Clark et al., 2002) and, manually or through automation, to schedule these applications to minimize water and nutrient losses (Haman and Smajstrla, 2002). Efficiency of application is enhanced by drip irrigation by the ability of only irrigating the soil root zone, thus reducing the net area irrigated. Sandy soil constraints such as low water and nutrientholding capacities can be overcome through multiple daily irrigations so that only the daily required amounts of water and fertilizer (Hochmuth and Smajstrla, 2003) are applied and the susceptibility of nutrient losses is minimized. The use of drip irrigation on the very sandy soils of Florida requires some other irrigation method (such as subirrigation) to ensure the optimum field soil moisture to enable preparation of the land (bed formation, fumigation, transplant establishment) for crop production. It is imperative that the design of a drip irrigation system results in uniform distribution of water throughout the cropped area (Smajstrla et al., 2002c). If the water distribution system is not designed (sized) properly, or length of run of individual drip irrigation lines is too long, inconsistent applications of both nutrients and water can result.

Although drip irrigation provides the highest potential for efficient water and nutrient application, a lack of high management intensity can negate that advantage quickly. Mismanaged drip irrigation can leach more nutrients than other systems if the fertilization program allows for application amounts greater than the soil's ability to maintain those nutrients in the rooting zone or when nutrients are applied followed by periods of extended irrigation.

Constraints associated with drip irrigation systems primarily deal with the high cost of installation and operation and the management intensity required to be successful. Drip irrigation has large investment costs associated with specific components needed for filtration, chemical injection, automated control as well as seasonal drip tube replacement. In addition, the training and experience that is necessary for successful drip irrigation management can be viewed as a constraint. This system requires a completely different mind set compared with seepage irrigation because a higher degree of attention to its management is necessary. If this constraint is not overcome, failure is likely to follow.

Overhead IRrigation. Traditional overhead irrigation of crops with widely spaced sprinklers can include solid set (permanently installed) systems, temporary moveable impact sprinkler systems, or self-propelled wide-area systems such as center pivot or lateral move systems. These systems are designed to apply water to the entire growing area and efficiencies are affected by evaporation losses and irrigation of noncropped areas. Because the entire area is irrigated, inherent losses by irrigating noncropped areas is evident.

Fertilization through overhead systems can be very risky for the same reason. For example, in citrus production, the use of inorganic fertilizers surface-applied near individual trees is a common practice. Because the fertilizer is exposed to potentially high rainfall events, it is vulnerable to leaching. This constraint can be reduced when applications are split during the production year, thus reducing the amount of fertilizer present in the field at any one time. Even so, this split application of fertilizer may be vulnerable to leaching. The use of controlled-release fertilizer to overcome this problem is an option, but the fertilizer costs are much higher.

Microsprinkler irrigation. An alternative to overhead systems (for perennial crops) is the microsprinkler system. Much like drip irrigation, the system is designed to apply water to part or all of the root zone only when desired and eliminates irrigation of noncropped areas in contrast to overhead systems. Microsprinkler systems have the ability to apply nutrients as often as irrigation is scheduled, thus controlling the amount of fertilizer present in the soil at one time and reducing the leaching potential. 
Like with drip irrigation, the associated costs for this system are higher because similar components are needed for operation and maintenance. A similar higher level of management intensity is needed also to ensure that the system is operating properly and that problems with malfunctioning microsprinklers (breakage or clogging) are attended to.

\section{Question 2: How do drainage practices used by producers affect water and nutrient use efficiency for the following irrigation systems: seepage subirrigation, drip, microsprinkler, and overhead irrigation?}

Drainage during times of heavy rainfall is critical for crop survival to minimize exposure time of roots to low soil oxygen concentrations in the crop rooting zone. How soil aeration is achieved and the degree to that it occurs with respect to the irrigation system used can be important when trying to minimize water and nutrient losses. Low soil oxygen is primarily driven by rainfall and the soil characteristics and is magnified on soils with a naturally high water table and/or where water tables are elevated for seepage irrigation. As soon as rainfall begins, the irrigation distribution system becomes a drainage system and if the field is allowed to drain excessively, nutrients in solution may be leached quickly as the water table is lowered. In contrast, under the same circumstances but using drip irrigation with injected fertilizer, only nutrients that have been recently applied (typically a l-d requirement) are vulnerable to leaching.

The capture and reuse of runoff water for irrigation is a method in which increased water use efficiency can be realized and, in some degree, nutrients if they are present in the water reused. This system can be effective because less water would be necessary needed from other well or surface sources, but a large storage structure is needed and often water treatment is necessary if reused for drip, overhead, and microsprinkler systems. For the most part, drainage practices can contribute to the efficient use of water and nutrients, but the degree that drainage is managed is the constraint that must be overcome.

\section{Questions to consider as we move forward}

VISION: WHAT DOES THE INDUSTRY NEED TO DO BETTER? SOM commodity groups in Florida have embraced the use of more efficient BMPs (i.e., microirrigation, precise irrigation scheduling, fertigation) to a greater degree than other groups. In some cases, BMP adoption has occurred because of necessity, but also there have been those commodity groups that could see potential economic advantages that existed to make the change. Increased communication of examples of success among and within commodity groups is needed. Regardless, horticultural producers should be encouraged to pay more attention to management of whatever practices they are using, consider all options when making management decisions, and be aware of all the resources that are available to improve the efficiency of operation.

Where SHOULD THE FUTURE RESEARCH EFFORTS BE FOCUSED? Certainly new technologies will be developed and as they are, evaluation and refinement should be a focus of future research. A component of communicating effectiveness of current and new BMPs requires field validation to gain the confidence of producers that what may be recommended in the future will benefit their operation. Also, as continued land use changes occur with population growth, more effort should be concentrated on the impacts of these land use changes on water quality, especially on natural resources such as drinking water sources or bays and estuaries for coastal Florida.

WHAT ARE THE CRITICAL ISSUES ON THE HORIZON THAT MAY AFFECT THE INDUSTRY? Coping with increased regulations for water quantity and quality management are major issues that the industry faces now and will continue to face. As increased competition for them continues and stronger policies to protect these resources are imposed, producers will have to determine whether they can continue to operate under such an environment. However, these are not the only issues that continue to give the agricultural problems. Included are issues such as labor availability, foreign competition, and invasive and new pest problems. It is essential that research and extension efforts are focused on ensuring a viable and growing industry in light of the many issues that are present.

In summary, horticultural producers face many constraints that can affect how efficiently they use water and nutrients. These constraints can be a result of the environmental, physical, and cultural growing conditions, but also can include economic and regulatory issues. Although many of these constraints can be overcome with the use of BMPs, economic and environmental success is a direct function of producer management decisions and the intensity to which they are implemented. Our focus must be on the future, demonstrating to producers that current technologies are effective in achieving water and nutrient use efficiency, developing and evaluating new technologies that will improve efficiency even further, and being aware that as land use changes continue to occur, our focus may shift to more agricultural/urban fringe issues that may involve even more urban landscape management of water quality.

\section{Literature cited}

Clark, G.A. and D.Z. Haman. 2003. Microirrigation in mulched bed production systems: Irrigation depths. Florida Coop. Ext. Serv., Inst. Food Agr. Sci., Univ. Florida, Fact Sheet AE-49. 19 May 2009. <http://edis.ifas.ufl.edu/AE049>.

Clark, G.A., C.D. Stanley, and A.G. Smajstrla. 2002. Micro-irrigation on mulched bed systems: Components, system capacities, and management. Florida Coop. Ext. Serv., Inst. Food Agr. Sci., Univ. Florida, Bul. 245. 19 May 2009. <http://edis.ifas.ufl.edu/AE042>.

Geraldson, C.M. 1962. Growing tomatoes and cucumbers with high analysis fertilizers and plastic mulch. Proc. Florida State Hort. Soc. 75:253-260.

Geraldson, C.M. 1980. Importance of water control for tomato production using the gradient mulch system. Proc. Florida State Hort. Soc. 93:278-279.

Geraldson, C.M., A.J. Overman, and J.P. Jones. 1965. Combination of high analysis fertilizers, plastic mulch, and fumigation for tomato production on old agricultural land. Soil Crop Soc. Florida Proc. 25:18-24.

Haman, D.Z. and F.T. Izuno. 2003. Soil plant water relationships. Florida Coop. Ext. Serv., Inst. Food Agr. Sci., Univ. 
Florida, Circ. 1085. 19 May 2009. $<$ http://edis.ifas.ufl.edu/AE021 >.

Haman, D.Z. and A.G. Smajstrla. 2002. Scheduling tips for drip irrigation of vegetables. Florida Coop. Ext. Serv., Inst. Food Agr. Sci., Univ. Florida, Fact Sheet AE-249. 19 May 2009. <http://edis.ifas. ufl.edu/document_ae092>.

Haman, D.Z. and A.G. Smajstrla. 2003. Design tips for drip irrigation of vegetables. Florida Coop. Ext. Serv., Inst. Food Agr. Sci., Univ. Florida, Fact Sheet AE260. 19 May 2009. <http://edis.ifas.ufl. edu/AE093>.

Hochmuth, G.J. and A.G. Smajstrla. 2003. Fertilizer application and management for micro (drip)-irrigated vegetables. Florida Coop. Ext. Serv., Inst. Food Agr. Sci., Univ. Florida, Circ. 1181. 19 May 2009. <http://edis.ifas.ufl.edu/CVl4l>.

Simonne, E.H., M.D. Dukes, and D.Z. Haman. 2007. Principles and practices of irrigation management for vegetables, p. 33-39. In: S.M. Olson and E.H. Simmone (eds.). Vegetable production guide for Florida 2007-2008. Univ. Florida, Gainesville, FL.
Simonne, E.H. and G.J. Hochmuth. 2007. Soil and fertilizer management for vegetable production in Florida, p. 3-14. In: S.M. Olson and E.H. Simmone (eds.) Vegetable production guide for Florida 2007-2008. Univ. Florida, Gainesville, FL.

Smajstrla, A.G., B.J. Boman, G.A. Clark, D.Z. Haman, D.S. Harrison, F.T. Izuno, D.J. Pitts, and F.S. Zazueta. 2002a. Efficiencies in Florida agricultural irrigation systems. Florida Coop. Ext. Serv., Inst. Food Agr. Sci., Univ. Florida, Bul. 247. 19 May 2009. <http://edis.ifas.ufl. edu/AE110>.

Smajstrla, A.G., B.J. Boman, D.Z. Haman, D.J. Pitts, and F.S. Zazueta. 2002b. Field evaluation of microirrigation water application uniformity. Florida Coop. Ext. Serv., Inst. Food Agr. Sci., Univ. Florida, Bul. 265. 19 May 2009. <http://edis.ifas. ufl.edu/AE094>.

Smajstrla, A.G., F.S. Zazueta, and D.Z Haman. 2002c. Potential impacts of improper irrigation system design. Florida Coop. Ext. Serv., Inst. Food Agr. Sci., Univ. Florida, Fact Sheet AE-73.
19 May 2009. <http://edis.ifas.ufl.edu/ AE027>.

Smajstrla, A.G., B.J. Boman, D.Z. Haman, F.T. Izuno, D.J. Pitts, and F.S. Zazueta. 2006a. Basic irrigation scheduling in Florida. Florida Coop. Ext. Serv., Inst. Food Agr. Sci., Univ. Florida, Bul. 249. 19 May 2009. <http://edis.ifas.ufl.edu/ AE111>.

Smajstrla, A.G., G.A. Clark, and D.Z. Haman. 2006b. Florida irrigation systems. Florida Coop. Ext. Serv., Inst. Food Agr. Sci., Univ. Florida, Circ. 1035. 19 May 2009. <http://edis.ifas.ufl.edu/ AE385>.

Stanley, C.D. 2004. Effect of water table depth and irrigation application method on water use for subirrigated fresh market tomato production in Florida. J. Soil Water Conserv. 59:149-153.

Stanley, C.D. and G.A. Clark. 1991. Water table management using microirrigation tubing. Soil Crop Sci. Soc. Florida Proc. 50:6-8. 